\title{
Interactions between foliar diseases: Concepts and epidemiological approaches
}

\author{
Waldir C. Jesus Junior'1, Trazilbo J. Paula Júnior², Miller S. Lehner ${ }^{3}$ \& Bernhard Hau ${ }^{4}$ \\ ${ }^{1}$ Departamento de Produção Vegetal, Universidade Federal do Espírito Santo, 29500-000, Alegre, ES, Brazil; ${ }^{2}$ EPAMIG, \\ Vila Gianetti 47, 36570-900, Viçosa, MG, Brazil; ${ }^{3}$ Programa de Pós-graduação em Genética e Melhoramento, Universidade \\ Federal de Viçosa, 36570-900, Viçosa, MG, Brazil; ${ }^{4}$ Institut für Pflanzenkrankheiten und Pflanzenschutz, Leibniz Universität \\ Hannover, Herrenhäuser Str. 2, 30419, Hannover, Germany
}

Author for correspondence: Waldir C. Jesus Junior, e-mail: wcintra@cca.ufes.br

\begin{abstract}
This review deals with the phenomenon of plant disease interactions. The epidemiological implications of foliar diseases occurring simultaneously on the same crop are important because the establishment of disease management strategies depends on the knowledge of disease interactions. We discuss some concepts and the terminology related to the interaction studies and present related examples with special emphasis on interacting wheat diseases.
\end{abstract}

Key words: crop loss, disease dynamics, multiple diseases.

\section{INTRODUCTION}

The occurrence of two or more pathogens simultaneously on the same host is frequent in many production systems (Zadoks \& Schein, 1979; Kranz \& Jörg, 1989). This situation may be even more recurrent in many tropical areas, where environmental conditions are mostly favourable to the occurrence of diseases during all periods of the year. Little is known about the combined effects of diseases on crop yield and only a few epidemiological studies on this subject have been carried out. Estimates of disease effects on yield are usually made assuming that each disease acts independently. Interactions of diseases can increase crop damage and complicate the identification of primary causes of diseases and their control. The interactions may alter the occurrence and speed of epidemics. Weber et al. (1994), for instance, concluded for the two wheat pathogens Septoria nodorum and Erysiphe graminis that wherever the two pathogens occur together, neither their dynamics, nor the influence of external factors could be understood, if interspecific interactions are neglected. Interactions may have significant implications for assessing crop losses, diagnosing the causes of these losses and for selecting appropriate management strategies, as well as for forecasting, modelling and simulations of epidemics (Waller \& Bridge, 1984; Bassanezi et al., 1998). Estimates of yield losses caused by several diseases made by adding of single disease yield-loss models are likely to be inaccurate if interactions are occurring (Zhou et al., 2000). Interactions may be important because the expected benefit from the control of one pathogen depends on the level of the other pathogens (Johnson et al., 1986) and therefore multiple diseases can significantly alter economic decision criteria in comparison to single disease occurrence (Pinnschmidt, 1991). According to Newton et al., (2010), new approaches in agronomy, crop protection and breeding could be achieved by understanding the population dynamic balance between the organisms of the phyllosphere as an ecological system.

The objectives of studies in multiple-disease situations usually can be divided into understanding (i) the population dynamics of interacting diseases and (ii) the combined effect on crop yield or yield loss. Once the specific effects of combined pathogens are understood, the question shifts towards how to manage a crop grown under combined infection conditions (Johnson, 1990). The examples of interactions presented in literature are mainly dealing with their effects on yield. Epidemiological aspects of these interactions in terms of changes in the component analysis have rarely been studied (Zadoks \& Schein, 1979; Weber et al., 1994). Here some aspects related to the dynamics and to crop losses of the interactions between diseases caused by aerial pathogens are discussed. The discussion will be restricted to the relationships between two or more aerial pathogens on the same host. Crossprotection and biological control will be not emphasized, although in these cases some kind of interactions can occur between the organisms involved.

\section{TERMINOLOGY}

Terms like interaction, association, interference and interrelationship have been used to describe relationships among diseases. In many cases these terms are used in an 
improper manner (Wallace, 1983; Sikora \& Carter, 1987). According to Wallace (1983), the various etiological agents can influence each other in their effects on the plant; that is, they interact. Consequently, the effect of the contribution of different pathogens on the same host may not be purely additive. As diseases can interact in their dynamics and/ or in their effects on crop loss, it is necessary to classify the interactions for both aspects. Sometimes there is no significant interaction between two diseases with respect to yield, although one disease affects the development of the other (Simkin \& Wheeler, 1974). For a given combination of pathogens, the type of interaction may change under different conditions or during successive stages in their life histories. Mixtures of synergistic and antagonistic interactions, creating usually unpredictable biological and epidemiological consequences, are likely to occur in plants, as Syller (2012) observed for interacting viruses.

\section{Interactions concerning the disease dynamics}

Several terms have been proposed to qualitatively describe interactions while quantitative methods seem to be used scarcely. The interactions between two and more diseases on a common host may produce antagonistic or protective, mutually exclusive, additive, or synergistic effects in the host (Damsteegt et al., 1993). An interaction between different pathogens can be antagonistic or protective when one inhibits or reduces the development of another (Latch \& Potter, 1977). A mutually exclusive interaction occurs when the development of all involved pathogens is reduced (Jedlinski \& Brown, 1965). An interaction is additive when the development of one pathogen is not altered in the presence of another and vice versa (Gordon \& Schmitthenner, 1969). When there is some enhancement in the development of one or more interacting pathogens, the interaction is called synergistic (Beute, 1973).

In ecology, one population can influence a second one in different ways, whereby the effect can be positive $(+)$, negative (-) or neutral (0). On the other hand, the second population can also affect the first one. Odum (1953) defined in an ecological sense that populations of two species may interact theoretically in six basic ways, corresponding to the six combinations of $0,+$, and -, as follows: 00 (neutralism), -- (competition), ++ (mutualism or protocooperation), +0 (commensalism), - 0 (amensalism), and +- (parasitism or predation). Although many types of direct effects of an organism on another can occur, indirect effects through the host plants seem to explain most of the cases of interacting diseases (Waller \& Bridge, 1984). Sometimes it is even not clear whether there are any antagonistic or synergistic effects of interacting pathogens, like with Alternaria porri and Stemphylium vesicarium which often occur together in the same purple leaf blotch lesion on Allium species (Suheri \& Price, 2000). In some cases the interactions between two diseases may not be detectable due to clear differences in time of disease onset or low disease levels, like for anthracnose (Colletotrichum sublineolum) and leaf blight (Exserohilum turcicum) on sorghum in Kenya (Ngugi et al., 2000).

In situations involving the simultaneous occurrence of aerial pathogens on the same plant, terms "interactions between diseases" and "interactions between pathogens" are practically similar. However, approaches involving this subject should focus on the interactions between diseases, since, in many cases, there are indirect effects mediated by the host.

\section{Interactions concerning crop losses}

Similar to the definition of interactions with respect to disease dynamics, the interactions related to yield or yield loss are termed in different ways although the terms seem to be clearer. There are three outcomes of combined effects of diseases on crop loss (Waller \& Bridge, 1984): the combined loss is equal to (no interaction, additive), more than (greater-than-additive, synergistic, positive interaction), or less than (less-than-additive, antagonistic, negative interaction) the sum of yield losses from individual diseases alone. According to the literature survey of Johnson (1990), studies of the effects of multiple pest and diseases on crop yield mostly report antagonistic interactions, which may result from competition between pathogen populations or from stimulation of active defence mechanisms in the host. Reports of synergistic interactions are relatively rare (Johnson, 1990). The synergistic interactions seem to operate through effects on host resistance permitting a pathological succession rather than by direct mutual synergism of pathogens (Waller \& Bridge, 1984).

\section{EXAMPLES OF DISEASE INTERACTIONS}

Some data concerning interactions between aerial diseases are presented in the Tables 1, 2 and 3. In some pathosystems, the determination of the type of interaction concerning dynamics aspects and/or crop loss is demonstrated. Criteria utilized to classify the interactions in terms of dynamics and crop loss were made considering three categories - antagonistic, synergistic and additive interactions.

It is important to emphasized that two plant pathogens can interact as antagonists "in vitro", however the diseases as a result of their infections on the same host can present an additive effect. Thus, it is not appropriate to do generalizations.

\section{CASE STUDY: RESULTS OBTAINED FROM PUBLISHED STUDIES ON WHEAT DISEASES}

Most of the cases of interaction between foliar diseases reported in the literature is related to wheat. This crop can be infected by many pathogens singly or simultaneously. Although wheat is a crop of temperate regions, it has been cultivated in many tropical areas, which may contribute to increase the frequency of interaction cases. In Brazil, for 


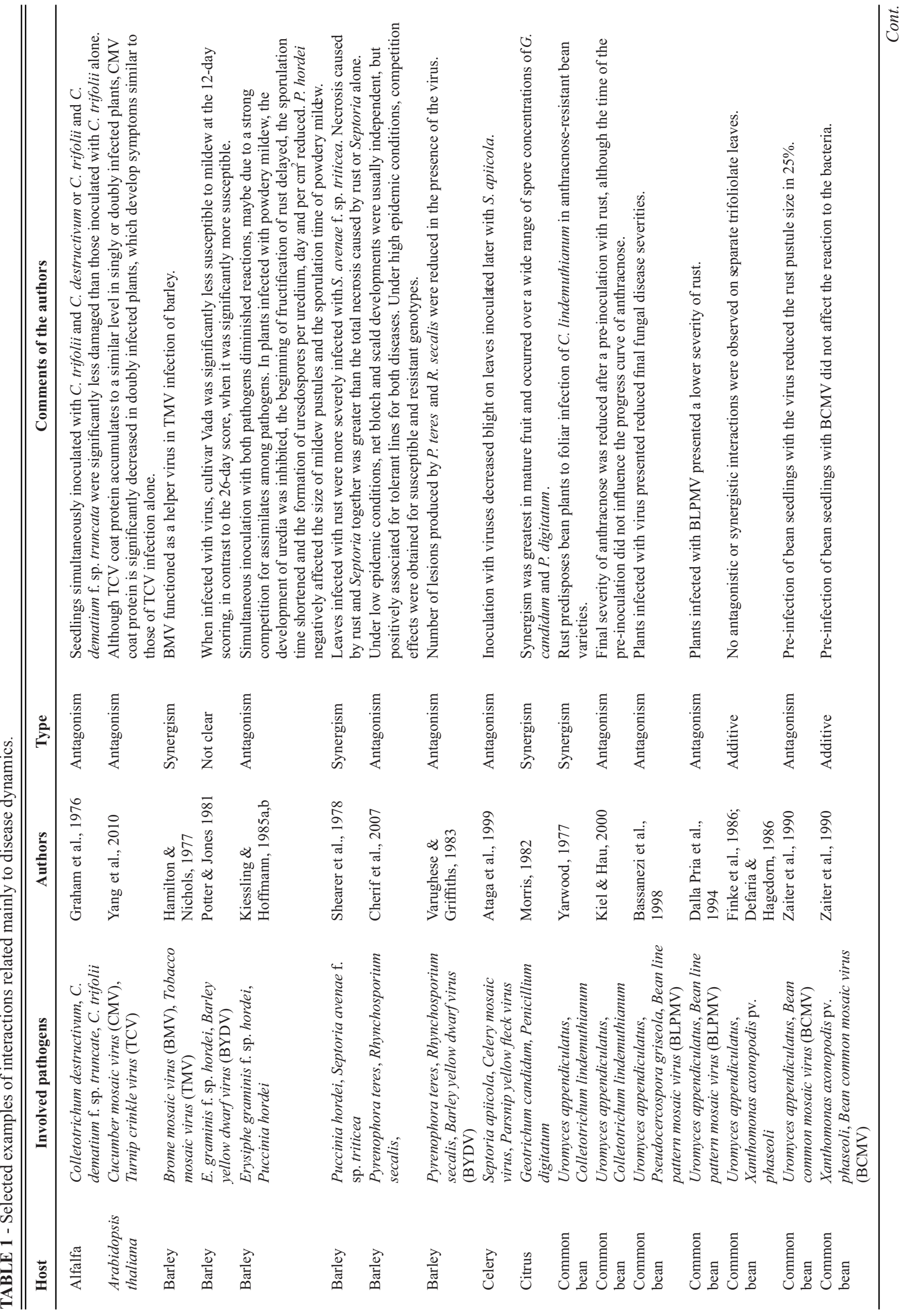


W.C. Jesus Junior et al.

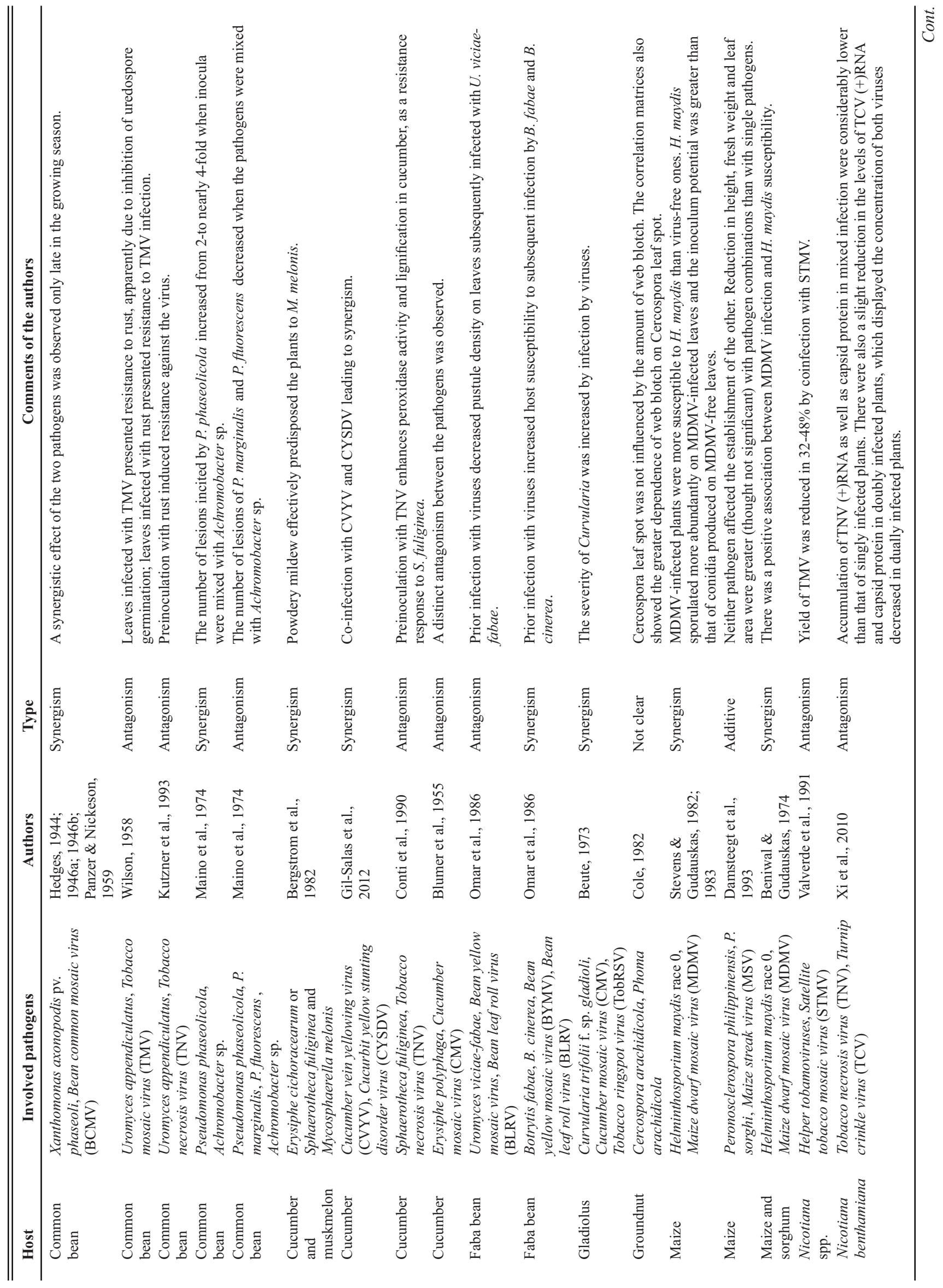


Interactions between foliar diseases: Concepts and epidemiological approaches

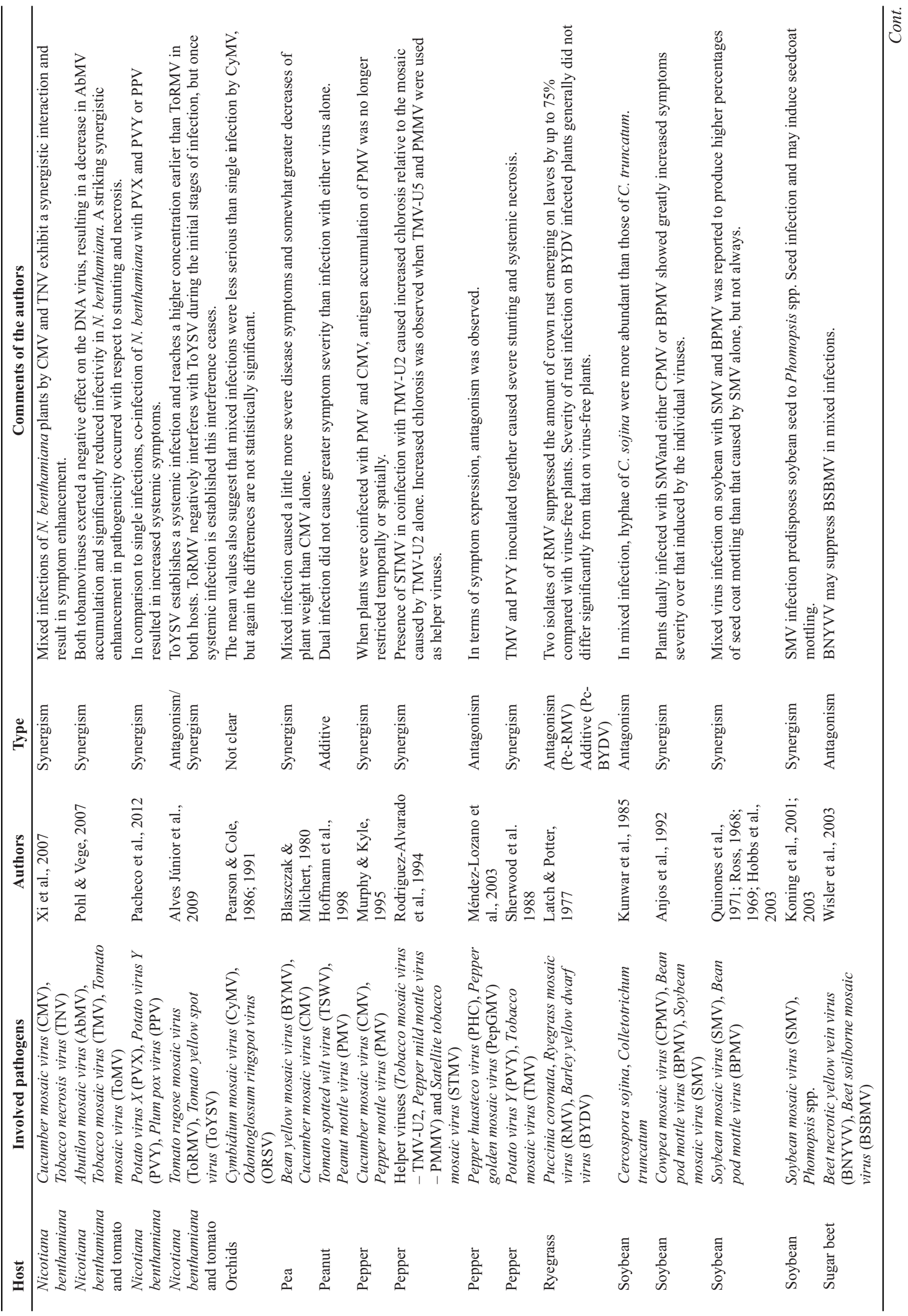


W.C. Jesus Junior et al.

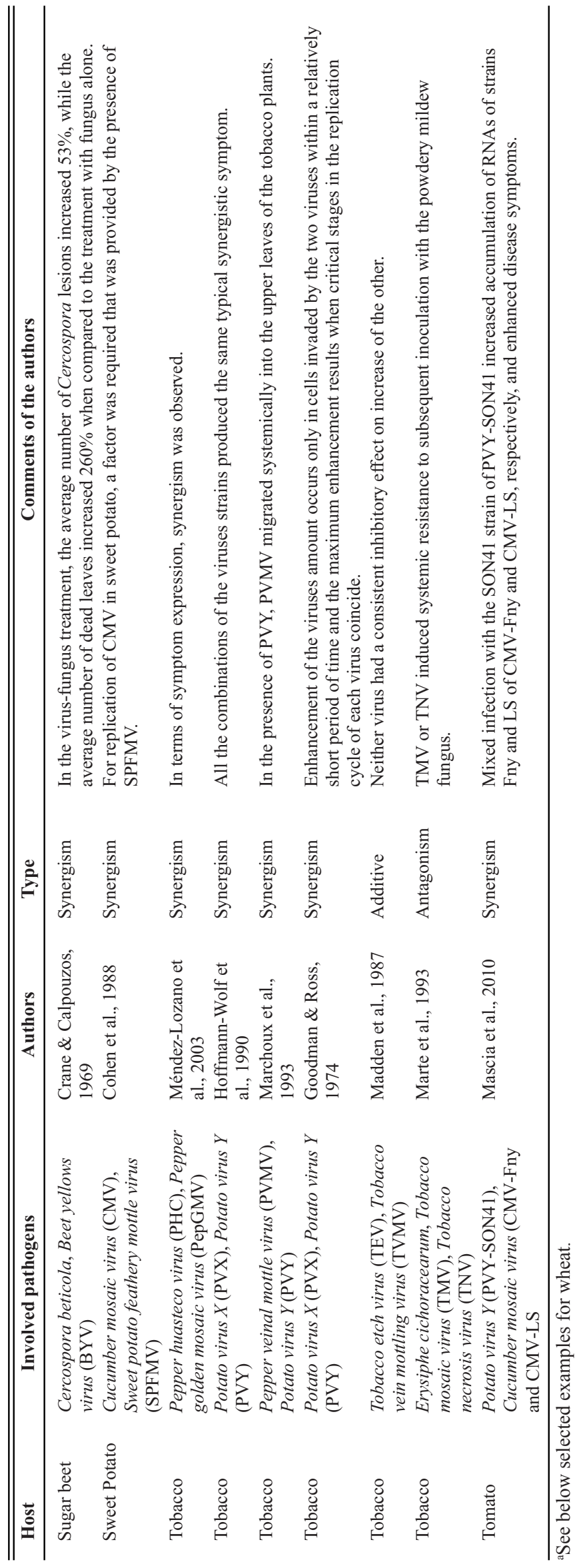


Interactions between foliar diseases: Concepts and epidemiological approaches

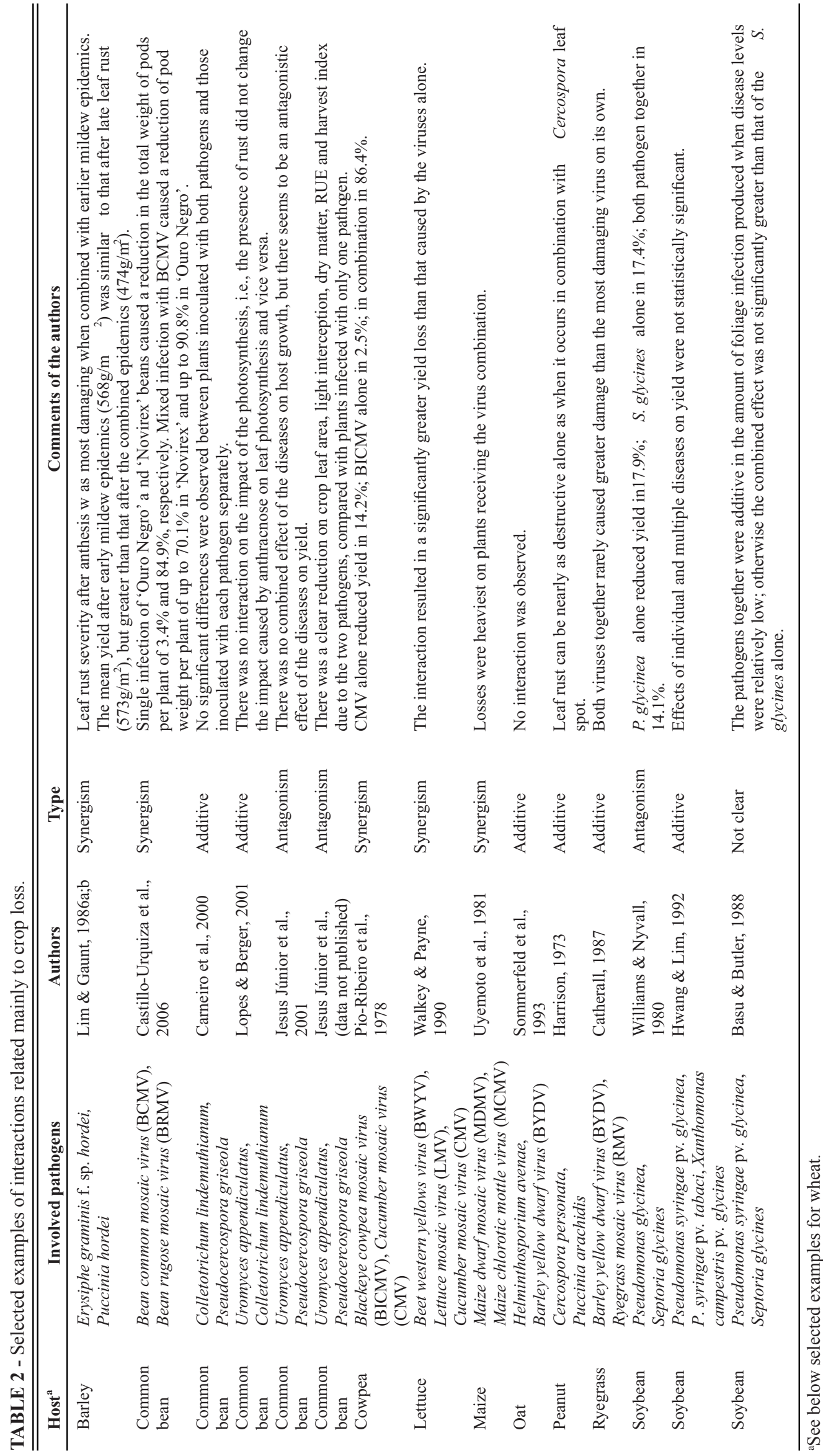


W.C. Jesus Junior et al.

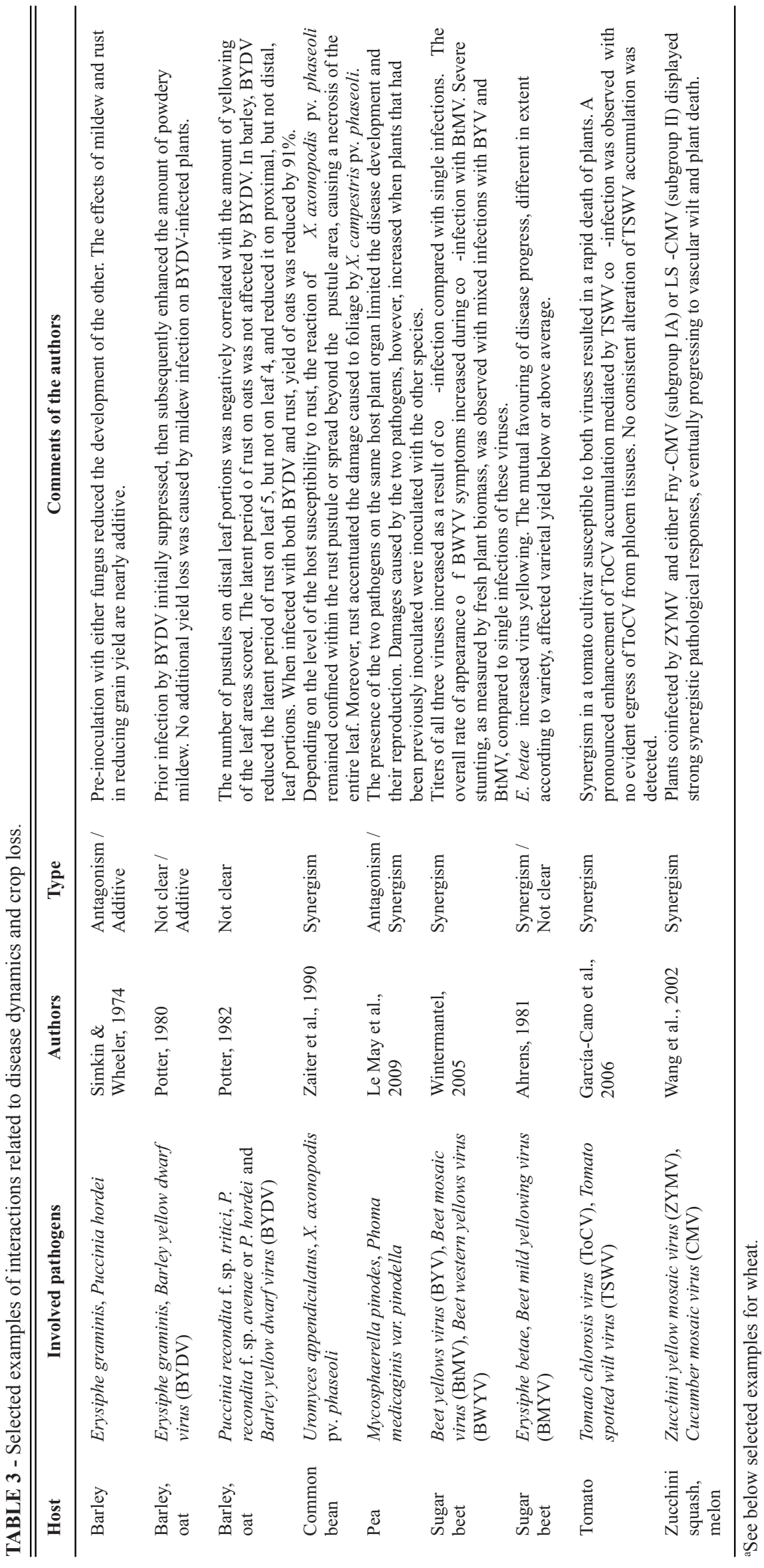


example, wheat is being introduced gradually in the cerrado areas usually under irrigation, which may be favourable to the infection by foliar pathogens.

Different parts of the wheat plant can be infected by different pathogens at the same time (Bonfig-Picard \& Kranz, 1984). These pathogens can naturally interact with each other. Interactions between diseases caused by aerial pathogens on wheat have frequently been demonstrated, mainly with respect to the dynamics of the pathogens. However, even for wheat, the crop that receives the most attention regarding interactions among diseases, there are little multi-disease studies concerning management or epidemiological approaches. Moreover, the observed effects of reported interactions (for instance synergism, antagonism or additive effect) are highly dependent on inoculum concentration, disease levels (Jörg, 1987; Weber et al., 1994), pre-infection by one of the interacting pathogens (Donchev et al., 1980), and climatic conditions (Weber et al., 1994). Cox et al. (2004) have demonstrated the potential of cultivar mixtures for the simultaneous management of tan spot (Pyrenophora tritici-repentis) and leaf rust of wheat (Puccinia triticina).

Johnston (1934) observed that uredospores of Puccinia recondita f. sp. tritici could develop on normally resistant varieties of wheat when the leaves were infected with Erysiphe graminis f. sp. tritici before the rust inoculation. Similarly, Manners \& Gandy (1954) reported higher susceptibility to $P$. recondita of some wheat varieties infected with mildew. However, when mildew severity was high, the rust development was limited. On the other hand, the severity of mildew was significantly reduced on wheat plants previously inoculated with $P$. recondita, maybe due to biochemical changes in the plants (Donchev et al., 1980).

In many studies, it has been demonstrated that one pathogen is promoted by another. Plants infected with Tilletia caries are more susceptible to $P$. striiformis (Straib, 1938). In the presence of Ustilago nuda, the damage by $P$. graminis f. sp. tritici is higher (Hart, 1931 cited by Straib, 1938, Thomas \& Chatarth, 1976). Raju et al. (1969) found that the number of pustules of $P$. recondita was increased in the presence of wheat streak mosaic virus (WSMV). In the same way, the number and the size of lesions caused by Helminthosporium sativum was higher when the plants were infected by WSMV (Adlakha \& Raychaudhuri, 1975). Wainwright et al., (1986) observed that $S$. nodorum caused more damage than $T$. caries. According to Willingale \& Mantle (1987) it was evident in the interaction involving Claviceps purpurea and $T$. caries that invasion by $C$. purpurea was essentially a displacement phenomenon, which characterize $C$. purpurea parasitism of healthy ovaries. The establishment of the sphacelium and subsequent differentiation to sclerotial tissue was more rapid in bunted rather than non-bunted ovaries.

One pathogen can also inhibit the development of another. Damage caused by Urocystis agropyri is reduced in the presence of $T$. controversa (Holton \& Jackson, 1951).
The severity of Helminthosporium blight (H. sativum) was lower in plants infected with $U$. nuda (Thomas \& Chatarth, 1976). Jones \& Roane (1982) found that Xanthomonas campestris pv. undulosa reduced germination and the length of germinative tube of spores of $S$. nodorum. Potter (1982) observed that, in plants infected with barley yellow dwarf virus (BYDV), the severity of $P$. recondita was lower, although the latent period was not affected. When infected with both BYDV and rust, yield was reduced by $63 \%$. Erasmus \& Von Wechmar (1983) observed that wheat plants with brome mosaic virus (BMV) were found less susceptible to $P$. graminis f. sp. tritici infection than virus-free plants. Adee et al. (1990) found that competition occurred between Pyrenophora tritici-repentis and S. nodorum. Sporulation by Puccinia triticina was reduced substantially by the presence of Pyrenophora tritici-repentis; in contrast, the presence of Puccinia triticina sometimes increased sporulation of Pyrenophora tritici-repentis (Al-Naimi, 2003).

No interaction was observed for the combinations P. striiformis x U. agropyri (Purdy \& Holton, 1963) and S. nodorum x S. tritici (Jenkins \& Jones, 1981). Hyde (1981) observed no interaction for the combination $S$. nodorum $\mathrm{x} P$. striiformis regarding seed weights, although the proportion of diseased leaves for the combination was less than the sum of effects of each pathogen occurring alone. Jones et al. (1981) observed that the apparent photosynthetic rate and transpiration rate of flag leaves did not differ statistically in the $X$. translucens f. sp. undulosa $+S$. nodorum treatment compared with $S$. nodorum alone. At lower incubation temperatures, combined inoculation had no effect compared with inoculation with either organism alone.

Van der Wal et al. (1970) and Van der Wal \& Cowan (1974) observed synergistic effect on crop losses when they studied the combination $P$. recondita $\mathrm{x} S$. nodorum. Van der Wal et al. (1970) observed also that on plants infected by $P$. recondita, the intensity of glume blotch symptoms caused by $S$. nodorum was greater than on not inoculated plants. They observed also that, in the presence of $S$. nodorum, the production of uredospores of $P$. recondita was reduced while the production of teliospores was stimulated. The loss caused by the interacting fungi is significantly larger than the calculated sum of the losses caused by each fungus alone. Wheat plants infected by $P$. recondita were predisposed to infection by $S$. nodorum (Van der Wal \& Cowan, 1974). According to these authors the effect of both pathogens together on the dry weight of the heads was greater than the sum of the effects of each of the pathogen separately. However, no interaction was observed when the infection by $S$. nodorum occurred before $P$. recondita infection (Hyde, 1978). Spadafora \& Cole (1987) found an inverse relationship between the severities of $P$. recondita and $S$. nodorum.

Broscious et al. (1982) and Bonfig-Picard \& Kranz (1984) have observed a competition between populations of S. nodorum and E. graminis f. sp. tritici. Geuting (1984) found that in the presence of $S$. nodorum the number of 
mildew colonies was lower and the colonies were smaller compared to the control plants. The number of conidia/ colony was also lower. The latent period of $S$. nodorum was shortened in the presence of $E$. graminis f. sp. tritici. Jörg (1987) confirmed under field conditions the results of Geuting (1984), although he found no influence of $E$. graminis on $S$. nodorum. The development of mildew was inhibited in the presence of $S$. nodorum and the effect was more pronounced at high severity of the diseases. Similarly to Geuting (1984), Brokenshire (1974) observed reduced latency duration of $S$. tritici in the presence of E. graminis. Resistant plants were susceptible to $S$. tritici in the presence of mildew. There was an inverse relationship, based on individual replicate values, between the pre-inoculation mildew treatments and the latent period of $S$. tritici, but a significant positive correlation for the sporulation index. For this combination, Madariaga \& Scharen (1984) observed that in the presence of $S$. tritici, the effect of $P$. striiformis was always reduced by the presence of $M$. graminicola. The two pathogens could colonize the same leaf simultaneously, and the diseased area was similar or smaller than the area affected by each pathogen separately. A smaller amount of leaf tissue was colonized by $P$. striiformis when $M$. graminicola was present. M. graminicola acted as a hypostatic parasite.

Weber et al. (1994) observed that, in greenhouse, $S$. nodorum reduced the severity of mildew. On the other hand, under field conditions, E. graminis increased the final intensity of $S$. nodorum. The apparent contradiction was explained as a result of different climatic conditions, which allowed secondary infections of $S$. nodorum in the field. Based on the studies of Brokenshire (1974), Geuting (1984) and Jörg (1987), Weber et al. (1994) concluded that these pathogens couldn't strictly be described as competitors sensu Odum (1953). The relation between $E$. graminis and $S$. nodorum is better described, sensu Powell (1979), as "predisposition with dominance of the secondary pathogen", with E. graminis as primary, and S. nodorum as secondary pathogen (Jörg, 1987; Weber et al., 1994).

Tatineni et al. (2010) studied the double infection of wheat cultivars with Triticum mosaic virus (TriMV), the type member of the Poacevirus genus, and Wheat streak mosaic virus (WSMV), the type member of the Tritimovirus genus, both of the family Potyviridae. They found that double infections in wheat cvs. Arapahoe and Tomahawk induced disease synergism with severe leaf deformation, bleaching, and stunting, with an increase in accumulation of both viruses over single infections at 14 days post inoculation.

\section{QUANTIFYING INTERACTIONS}

\section{Interactions in disease dynamics}

As mentioned above, the interactions between pathogens or diseases can be of various natures, for instance characterised as competition, symbiosis, parasitism, etc. Independent of the kind of interactions, the effect is reflected in changes of the disease progress curves compared to the situation in which each disease is occurring alone. Some research has been published showing the effect of the preinfection of one disease on a second disease. A detailed study for this approach to interactions was presented by Bassanezi et al. (1998) who investigated the effect of pre-infection with Bean line pattern mosaic virus (BLPMV) on some elements of Uromyces appendiculatus and Phaeoisariopsis griseola over a wide range of temperatures. Other studies have applied the de Wit replacement series technique to investigate the outcome of competitive interactions between two plant pathogens using the conidial production (Adee et al., 1990; Nolan et al., 1999). In order to compare epidemics of interacting diseases, the area under the disease progress curve have been calculated and analysed using analyses of variance (Savary \& Zadoks, 1992a).

In many publications the disease dynamics of single diseases is modelled, but only a few examples have been published in which the progress of epidemics in a multiple disease situation has been quantified and modelled. This approach will be discussed in more detail, starting with the classical Lotka-Volterra competition model. Madden et al. (1987) applied the classical Lotka-Volterra competition equations to model the disease progress curves of the disease incidence of tobacco etch virus (TEV) and tobacco vein mottling virus (TVMV). The model is based on the assumption that the disease progress curves are logistic functions if one disease would be there alone. The competition model is given by the following system of differential equations for the disease severity or incidence of two diseases $y_{1}$ and $y_{2}$ given as proportions with values between 0 and 1 :

$\mathrm{d} y_{l} / \mathrm{d} t=r_{1} y_{1}\left(1-\left[y_{1}+\alpha a_{12} y_{2}\right] / K_{l}\right)$

$\mathrm{d} y_{2} / \mathrm{d} t=r_{2} y_{2}\left(1-\left[y_{2}+\alpha a_{21} y_{1}\right] / K_{2}\right)$

The parameters $r_{1}$ and $r_{2}$ are the apparent infection rates and $K_{1}$ and $K_{2}$ the maximum disease levels of both diseases in absence of the other disease. The two parameters $\alpha a_{12}$ and $\alpha a_{21}$ are the coefficients of competition. The coefficient $\alpha a_{12}$ indicates the competitive effect of disease 2 on disease 1 . The system of differential equations (eq. 1) can be re-arranged to point out the mutual effects of the diseases on each other:

$\mathrm{d} y_{l} / \mathrm{d} t=r_{1}\left(1-\alpha a_{12} y_{2} / K_{l}\right) y_{1}\left(1-y_{1} /\left[K_{l}\left(1-\alpha a_{12} y_{2} / K_{l}\right)\right]\right)$ $\mathrm{d} y_{2} / \mathrm{d} t=r_{2}\left(1-\alpha a_{21} y_{1} / K_{2}\right) y_{2}\left(1-y_{2} /\left[K_{2}\left(1-\alpha a_{21} y_{1} / K_{2}\right)\right]\right)$

The new system (eq. 2) clearly shows that the actual apparent infection rate and the actual maximum disease level of each disease are linearly decreasing with increasing severity of the other disease. Moreover, the reducing effect is identical to the rate and the capacity.

In the example of Madden et al. (1987) the dynamics of two tobacco virus diseases TEV (Tobacco etch virus $=$ 1 ) and TVMV (Tobacco vein mottling virus $=2$ ) occurring 
at the same time in tobacco fields were modelled. Disease incidence progression was quantified by fitting the LotkaVolterra equations (eq. 1), resulting in the following parameters values for the data set in 1984 B without insecticide usage: $r_{1}=0.223 /$ day, $r_{2}=0.261 /$ day, $K_{1}=0.175$, $K_{2}=1.00, \alpha a_{12}=0.06$ and $\alpha a_{21}=1.67$. From eq. 2 it can be concluded that the actual rate and the maximum disease level of TEV are reduced by $0.34 \%$ when the disease incidence of TVMV increases $1 \%$. The reduction of TVMV is $1.67 \%$ per $1 \%$ increase of TEV. Due to the interaction modelled as competition, the maximum disease levels of both diseases are reduced.

Ngugi et al. (2001) used the Lotka-Volterra equations (eq. 1) to simultaneously describe the disease progress curves of sorghum anthracnose (caused by Colletotrichum sublineolum) and leaf blight (caused by Exserohilum turcicum). In most cases the competition coefficients were not significantly different from 0 so they concluded that interactions between both diseases did not occur.

Although the Lotka-Volterra competition equations have been successfully applied in these examples, the general disease progression resulting from the model may not reflect interacting plant disease epidemics in a real situation. The equations allow a decrease in disease intensities, which is not possible without regarding changes of the host plant. Even under adverse conditions to the pathogen and the disease, the leaf area covered by disease symptoms cannot decrease and thus the disease levels in the worst case remain constant. Thus it is logical to demand that in the Lotka-Volterra equations the changes of the disease severity must be equal or greater than $0\left(d y_{1} / d t \geq 0\right.$ and $d y_{2} /$ $d t \geq 0$ ). This can be achieved by introducing the maximum function $\max (0 ; x)$ which is zero if $x$ is below 0 . The LotkaVolterra equations can then be replaced by the following model:

$\mathrm{d} y_{1} / \mathrm{d} t=\max \left(0 ; r_{1} y_{1}\left(1-\left[y_{1}+\alpha a_{12} y_{2}\right] / K_{1}\right)\right)$

$\mathrm{d} y_{2} / \mathrm{d} t=\max \left(0 ; r_{2} y_{2}\left(1-\left[y_{2}+\alpha a_{21} y_{1}\right] / K_{2}\right)\right)$

It must be pointed out that this more biological approach has a disadvantage as the equilibrium values of the interacting diseases are not fixed, like in the original Lotka-Volterra model, but depend on the initial disease values.

Weber (1996) used this approach to describe disease progress curves of wheat powdery mildew (E. graminis $\mathrm{f}$. sp. tritici) and leaf blotch disease (S. nodorum) and their interactions. In addition to this change of the Lotka-Volterra equations, he included a promoting effect as possible interaction between diseases, thus going beyondacompetition model. For the interactions between $E$. graminis, a biotrophic pathogen, and $S$. nodorum, a perthotrophic fungus (which initiates infection as a biotroph but spends most of its life cycle as a necrotroph), he assumed an inhibiting effect of $S$. nodorum on E. graminis and a disease-promoting effect of E. graminis on S. nodorum. This led to the following model for the interactions between the diseases whereby $y_{M}$ and $y_{S}$ represent the disease severities (as proportions) of powdery mildew and Septoria leaf blotch, respectively:

$\mathrm{d} y_{M} / \mathrm{d} t=\max \left[0 ; r_{M} y_{M}\left(1-y_{M} / K_{M}-a_{s} y_{S}\right)\right]$

$\mathrm{d} y_{S} / \mathrm{d} t=r_{S} y_{S}\left(1-y_{S} / K_{S}+a_{M} y_{M}\right)$

Again, $r_{M}$ and $r_{S}$ are infection rates, $K_{M}$ and $K_{S}$ the maximum severity levels of mildew and Septoria leafblotch, respectively, without mutual influences. The interaction term $a_{M}(>0)$ gives the influence of mildew on Septoria disease, and the coefficient $a_{s}(>0)$ the influence of Septoria leaf blotch on mildew. Here the Septoria disease is modelled adversely to mildew, as a competitor for infection places. However, the effect of mildew is incorporated as a factor delaying the density regulation of Septoria disease by the positive of sign. The function max prevents a decline of the mildew growth rate which can be biologically interpreted as the exclusion of the overgrowing of mildew lesions by Septoria leaf blotch.

To show the similarity to the Lotka-Volterra equations, Weber's system (eq. 4) can be re-arranged resulting in the following equations (eq. 5):

$\mathrm{d} y_{M} / \mathrm{d} t=\max \left\{0 ; r_{M}\left(1-a_{s} y_{S}\right) y_{M}\left(1-y_{M} /\left[K_{M}\left(1-a_{s} y_{S}\right)\right]\right)\right\}$

$\mathrm{d} y_{S} / \mathrm{d} t=r_{S}\left(1+a_{M} y_{M}\right) y_{S}\left(1-y_{S} /\left[K_{S}\left(1+a_{M} y_{M}\right)\right]\right)$

The effect of Septoria leaf blotch on mildew is reflected in the reduced infection rate as well as in the decreased maximum disease level of mildew. On the other side, increasing mildew severity raises the actual infection rate and the maximum disease level of Septoria disease. The relative changes of the rate and capacity parameter values as a result of the interaction are identical, negative for mildew, but positive for Septoria leaf blotch.

For data of disease progression in 1991, the following parameter values were estimated by Weber (1996): $r_{M}=0.2$ / day, $r_{S}=0.19$ / day, $K_{M}=0.07, K_{S}=0.334, a_{M}=17.13$ and $a_{S}=4.32$. Thus, an increase of Septoria disease by $1 \%$ reduces the mildew parameter values by $4.32 \%$, while a $1 \%$ increase of mildew raises the Septoria parameter values by $17.13 \%$. Simulated disease progress curves of both diseases in 1991 are calculated according to the modified LotkaVolterra equations (eq. 5) and under the assumption of no disease interaction.

In a second model, Weber (1996) assumed that mildew is not changing the maximum disease level of Septoria leaf blotch so that the model can be written as:

$\mathrm{d} y_{M} / \mathrm{d} t=\max \left\{0 ; r_{M}\left(1-a_{s} y_{S}\right) y_{M}\left(1-y_{M} /\left[K_{M}\left(1-a_{s} y_{S}\right)\right]\right)\right\}$

$\mathrm{d} y_{S} / \mathrm{d} t=r_{S}\left(1+a_{M} y_{M}\right) y_{S}\left(1-y_{S} / K_{S}\right)$

In contrast to the previous interaction models, the rate and capacity parameters are now not affected in the same way, as the capacity of Septoria leaf blotch remains unchanged in presence of powdery mildew. Weber (1996) 
also fitted this model to the data of disease progression in 1991 and determined the following parameter values: $r_{M}=$ $0.29 /$ day, $r_{S}=0.14 /$ day, $K_{M}=0.066, K_{S}=0.40, a_{M}=57.83$ and $a_{S}=3.29$. When the disease incidence of Septoria leaf blotch increases by $1 \%$, the actual rate and the maximum disease level of mildew are reduced by $3.29 \%$. A $1 \%$ increase of mildew increases the rate of Septoria disease by $57.83 \%$, however, without changing the maximum disease level of Septoria leaf blotch.

Following Weber's approach by assuming that in an interaction the rate and the capacity parameters are affected in the same direction but to a different extent, a general interaction model can be constructed:

$\mathrm{d} y_{l} / \mathrm{d} t=r_{l}\left(1-\alpha a_{12} y_{2} / K_{l}\right) y_{l}\left(1-y_{l} /\left[K_{l}\left(1-\beta b_{12} y_{2} / K_{l}\right)\right]\right.$

$\mathrm{d} y_{2} / \mathrm{d} t=r_{2}\left(1-\alpha a_{21} y_{1} / K_{2}\right) y_{2}\left(1-y_{2} /\left[K_{2}\left(1-\beta b_{2 l} y_{1} / K_{2}\right]\right)\right.$

The model would be more flexible because of additional parameters. The coefficients $\alpha a_{i j}$ describe the mutual effects on the rates and the $\beta b_{i j}$ on the maximum values. However, to our knowledge this approach has never been tested in explaining disease dynamics.

The models discussed so far describe the interactions of plant disease epidemics without taking into consideration the host plant. Host growth, however, can change the dynamic of diseases, leading for instance to a decrease in disease severity if the host is growing faster than the disease is progressing. Thus the host influences the disease dynamics. On the other hand, a disease can affect host growth in different ways, as classified by Boote et al. (1983). The mutual effects of host and diseases form another important interaction demanding an additional equation in interaction models to account for changes of the host plant. Waggoner (1986) and Jeger (1986) have dealt with analytical models to describe the dynamics of interacting host and disease. Hau \& Meier (1998) included the host dynamics when modelling the progression of different leaf diseases (U. appendiculatus, P. griseola and C. lindemuthianum) on Phaseolus beans. The coupling of pest and disease models with crop growth models forms an essential element in understanding the interactions among diseases and between diseases and host plants, especially with respect to the combined yield losses caused by several diseases (Boote et al., 1983; Rouse, 1988; Béasse et al., 2000).

\section{Interactions of diseases on yield or yield loss}

Compared to the quantification of interactions on the epidemic level, more information is available on the combined effect of multiple attacks on yield loss. A good example is the study of Johnson et al. $(1986,1987)$, in which the yield reduction in potato caused by early blight (A. solani), Verticillium wilt (Verticillium dahliae) and potato leafhopper (Empoasca fabae) was investigated. The principal conclusion from the field studies was that combined infestations resulted in yield and foliage losses that were less than the sum of losses from solitary infestations of each organism. In another study, Savary \& Zadoks (1992a, b, c) analysed the crop losses of groundnut due to a combined attack of rust ( $P$. arachidis) and late leaf spot (Cercosporidium personatum). The overall result indicated that the effects of the two diseases on damage were less than additive. Similarly, injuries caused by rice pathogens, insects and weeds were less than additive in their yield-reducing effects (Savary et al., 2000).

The effects of interacting pathogens on yield loss have been modelled using multiple regression equations (Savary \& Zakoks, 1992a; b), analysis of variance of factorial designs (Johnson et al., 1986; 1987), discriminant analysis (Francl et al., 1987), principal component analysis (Savary et al., 2000) or correspondence analysis (Savary \& Zadoks, 1992c; Savary et al., 2000).

Empirical yield-loss equations for a complex of diseases are often obtained via multiple regression analyses with yield or yield loss as the dependent variable. Disease parameters, used directly or after a transformation, serve as independent variables. For two diseases, the general equation for the total yield loss $(Y L)$ predicted is given as:

$$
Y L=b_{1} f_{1}\left(y_{1}\right)+b_{2} f_{2}\left(y_{2}\right)+b_{12} g\left(y_{1}, y_{2}\right)
$$

The two disease parameters, $y_{1}$ and $y_{2}$, could be disease severities which can be transformed with the functions $f_{1}$ and $f_{2}$. The coefficients $b_{1}$ and $b_{2}$ are the respective damage coefficients for the transformed values of $y_{1}$ and $y_{2}$. The third term is the interaction term of the model depending on the function $g$ of both disease severities. If the coefficient $b_{12}$ is equal 0 , the diseases reduce yield independent from each other. For $b_{12}>0$ the total yield loss is higher than the sum of the individual yield losses, for $b_{12}<0$ the effects of $y_{1}$ and $y_{2}$ are less than additive.

If the disease parameters represent disease incidence or disease severity at one time in the season, this equation reflects a so-called "single point" or "critical point model". The disease parameters could also be the areas under disease progress curves (AUDPC). A special case of this equation would be the well-known linear regression equation with an interaction term involving the multiplication of the disease parameters:

$$
Y L=b_{1} y_{1}+b_{2} y_{2}+b_{12} y_{1} y_{2}
$$

For the application of this model as a critical point model, the disease severities of both diseases at a certain point in time of the season must be known. These disease levels are a result of the dynamics of epidemics of the two interacting diseases. Thus the understanding of interactions of diseases with respect to their dynamics is a prerequisite to understand their combined effect on yield loss.

For some diseases it has been shown that yield or yield loss are not related to disease parameters, like 
the disease severity in a critical stage or the area under disease progress curve, for instance for angular leaf spot $(P$. griseola) on Phaseolus beans (Bergamin Filho et al., 1997). Therefore, it can be expected that an equation involving an interaction term by multiplying disease severities may also not be useful in predicting yield loss. Disease severity is a relative measure, which doesn't contain information on the total amount of leaf area. The latter, however, or other host parameters like the area under leaf area progress curve (AULAPC), may be strongly related to yield (Waggoner \& Berger, 1987). In such a case, useful predictions of yield loss can only be achieved by realistic estimations of the available leaf area. The dynamics of the leaf area is influenced by the disease progress, which in turn is affected by the leaf area available for infection. Thus without understanding the interactions between host dynamics and progression of epidemics, no appropriate yield loss prediction can be achieved. Consequently, crop growth simulation models, coupled with disease models have been applied to estimate crop losses (e.g. Johnson, 1992; Batchelor et al., 1993; Pinnschmidt \& Teng, 1994; Pinnschmidt, 1997) by identifying coupling points as described by Boote et al. (1983). Teng \& Johnson (1988) pointed out that "crop-pest models may be the only realistic way to understand or predict the effects of multiple pests on yield", but the application of this approach is rather limited still today.

Zhang et al. (2006) analyzed the relationship between winter wheat cultivar susceptibility to four main fungal diseases (Septoria tritici blotch, brown rust, yellow rust and powdery mildew), multiple disease systems, and yield loss (YL) levels. According to authors five potential disease profiles (PDP) were obtained. For all five PDP, cultivar susceptibility profiles (CP) 1 and CP3 (susceptible to Septoria tritici blotch and brown rust) consistently made a major contribution to $\mathrm{YL}$, whereas CP8 (most resistant to diseases) consistently contributed little to YL. The impact of CP5 (high susceptibility to Septoria tritici blotch and medium to high susceptibility to yellow rust) on YL is higher among the cultivar profiles for PDP5 (with the occurrence of yellow rust and Septoria tritici blotch) and also for PDP3 and PDP4 (no yellow rust but high intensity of Septoria tritici blotch), but is comparatively lower in the case of PDP1 and PDP2 (no yellow rust and nil to medium intensity of Septoria tritici blotch). Authors concluded that these results could be used to improve the disease module of an agronomic model for wheat aimed at designing "cultivar-crop management" combinations for a given environment and cost/price ratio.

In a previous review (Paula Júnior et al. 2010), it was discussed some aspects related to the epidemiology of interactions among diseases and concluded that there are only few studies that emphasize epidemiological aspects and they are not merely descriptive. We also assumed that although studies involving interactions between diseases still remain quite new, it is obvious for many pathosystems that significant progress in recommending the implementation of appropriate strategies of disease management can only be achieved by careful consideration of all implications related to the interactions.

\section{FINAL REMARKS}

It is evident that the interactions of different diseases occurring on one host are a very complex phenomenon. Although effects of some disease combinations on specific hosts, like Septoria disease and mildew on wheat, are known and intensively studied, effects of interactions in general cannot be anticipated. Nevertheless, it has been reported that combinations involving obligate pathogens and viruses frequently result in antagonism (Blumer et al., 1955; Wilson, 1958; Latch \& Potter, 1977; Potter, 1982; Erasmus \& Von Wechmar, 1983; Omar et al., 1986; Conti et al., 1990; Zaiter et al., 1990; Kutzner et al., 1993; Marte et al., 1993; Dalla Pria, 1994; Bassanezi et al., 1998). Conversely, combinations involving non-obligate pathogens and viruses often result in synergism (Hedges, 1944; 1946a; b; Panzer \& Nickeson, 1959; Crane \& Calpouzos, 1969; Beute, 1973; Beniwal \& Gudauskas, 1974; Adlakha \& Raychaudhuri, 1975; Stevens \& Gudauskas, 1982; 1983; Omar et al., 1986). For most combinations that may occur in the nature, results will depend on several factors. Methods of experimentation and assessment are important factors in interpreting results in interactions studies (Hyde, 1981; Sikora \& Carter, 1987), since sites and timing of inoculations, level of infection, host age, and many other host and pathogen characters may affect the disease outcome (Hyde, 1981).

Disease development under glasshouse conditions where environmental conditions may differ from those prevalent in the field can produce artificial or forced interactions. Normally the inoculum concentration, temperature, nutrition, relative humidity, wetness and others variables used in glasshouse experiments may not occur in the field or, if they occur, other interactions could make the interpretation of the data difficult. This review emphasizes the necessity of studies at field conditions to understand possible interactions.

Interaction between foliar diseases is a subject that should be not neglected in breeding programs, especially in tropical regions. Investigations should include inoculations of mixtures of inoculum from different pathogens and incorporation of genes that confer resistance to multiple pathogens.

\section{ACKNOWLEDGEMENTS}

W.C. Jesus Junior, T.J. Paula Júnior and M.S. Lehner are supported by Conselho Nacional de Desenvolvimento Científico e Tecnológico - CNPq. 


\section{REFERENCES}

Adee SR, Pfender WF, Hartnett DC (1990) Competition between Pyrenophora tritici-repentis and Septoria nodorum in the wheat leaf as measured with the de Wit Replacement series. Phytopathology 80:1177-1182.

Adlakha KL, Raychaudhuri SP (1975) Interaction between Helminthosporium sativum and mosaic streak virus. Zeitschrift für Pflazenkrankheiten und Pflanzenschutz 82:201-206.

Ahrens W (1981) Schadwirkung eines kombinierten Befalls des echten Rübenmehltaus (Erysiphe betae) und der Virusvergilbung an Zuckerrüben bei unterschiedlicher Mehltauanfälligkeit. Zeitschrift für Pflazenkrankheiten und Pflanzenschutz 88:221227.

Alves-Júnior M, Alfenas-Zerbini P, Andrade EC, Esposito DA, Silva FN, Cruz ACF, Ventrella MC, Otoni WC, Zerbini FM (2009) Synergism and negative interference during co-infection of tomato and Nicotiana benthamiana with two bipartite begomoviruses. Virology 387:257-266.

Al-Naimi FA (2003) The competitive interaction between Pyrenophora tritici-repentis and Puccinia triticina. MS Thesis, Kansas State University. Manhattan KS, USA.

Anjos JR, Jarlfors U, Ghabrial SA (1992) Soybean mosaic potyvirus enhances the titer of two comoviruses in dually infected soybean plants. Phytopathology 82:1022-1027.

Ataga AE, Epton HAS, Frost RR (1999) Interaction of virusinfected celery and Septoria apiicola. Plant Pathology 48:620626.

Bassanezi RB, Amorim L, Bergamin Filho A, Hau B (1998) Effects of bean line pattern mosaic virus on the monocyclic components of rust and angular leaf spot of Phaseolus bean at different temperatures. Plant Pathology 47:289-298.

Basu PK, Butter G (1988) Assessment of brown spot (Septoria glycines) alone and in combination with bacterial blight (Pseudomonas syringae pv. glycinea) on soybeans in a shortseason area. Canadian Journal of Plant Pathology 10:78-82.

Batchelor WD, Jones JW, Boote KJ, Pinnschmidt H (1993) Extending the use of crop models to study pest damage. Transaction of ASAE 36:1-8.

Béasse C, Ney B, Tivoli B (2000) A simple model of pea (Pisum sativum) growth affected by Mycosphaerella pinodes. Plant Pathology 49:187-200.

Benival SPS, Gudauskas RT (1974) Maize dwarf mosaic virus increases susceptibility of sorghum and corn to Helminthosporium maydis race T. Phytopathology 64:1197-1201.

Bergamin Filho A, Carneiro SMTPG, Godoy CV, Amorim L, Berger RD, Hau B (1997) Angular leaf spot of Phaseolus beans: Relationships between disease, healthy leaf area, and yield. Phytopathology 87:5056-515.

Bergstrom GC, Knavel DE, Kuc J (1982) Role of insect injury and powdery mildew in the epidemiology of the gummy stem blight disease of cucurbits. Plant Disease 66:683-686.

Beute MK (1973) Increased leaf exudation enhances Curvularia leaf spot severity in virus-infected Gladiolus. Phytopathology 63:1204-1205.

Blaszczak W, Milchert M (1980) Pea reaction to cucumber mosaic virus and bean yellow mosaic virus in greenhouse conditions. Journal of Phytopathology 99:310-317.

Blumer S, Stalder L, Harder A (1955) Über die gegenseitigen Beziehungen zwischen Gurkenmosaik und Gurkenmehltau. Phytopathologische Zeitschrift 25:39-54.

Bonfig-Picard G, Kranz J (1984) Untersuchung über Wechselwirkungen von Schadorganismen im Agro-Ökosystem Weizen. Journal of Plant Diseases and Protection 91:619-628.

Boote KJ, Jones JW, Mishoe JW, Berger RD (1983) Coupling pests to crop growth simulators to predict yield reductions. Phytopathology 73:1581-1587.

Brokenshire T (1974) Predisposition of wheat to Septoria infection following attack by Erysiphe. Transactions of the British Mycological Society 63:393-397.

Broscious SC, Frank JA, Cole Jr H (1982) Control of powdery mildew on wheat and its subsequent effect on Septoria severity and yield. Phytopathology 72:258.

Carneiro SMTPG (2000) Efeito da infecção conjunta de Phaeoisariopsis griseola e Colletotrichum lindemuthianum nos componentes de produção e nas variáveis de área foliar do feijoeiro. PhD Thesis, Universidade de São Paulo. Piracicaba SP, Brazil.

Catherall PL (1987) Effects of barley yellow dwarf and ryegrass mosaic viruses alone and in combination on the productivity of perennial and Italian ryegrasses. Plant Pathology 36:73-78.

Castillo-Urquiza GP, Maia FGM, Carvalho MG, Pinto CMF, Zerbini FM (2006) Caracterização de um isolado do Bean rugose mosaic virus (BRMV) de Minas Gerais e estimativa de perdas em feijoeiro em infecção simples ou em conjunto com o BCMV. Fitopatologia Brasileira 31:455-461.

Cherif M, Rezgui S, Devaux P, Harrabi M (2007) Interaction between Rhynchosporium secalis and Pyrenophora teres in the field and identification of genotypes with double resistance in a doubled-haploid barley population. Journal of Phytopathology 155:90-96.

Cohen J, Loebenstein G, Spiegel S (1988) Infection of sweet potato by cucumber mosaic virus depends on the presence of sweet potato feathery mottle virus. Plant Disease 72:583-585.

Cole DL (1982) Interactions between Cercospora arachidicola and Phoma arachidicola, and their effects on defoliation and kernel yield of groundnut. Plant Pathology 31:355-362.

Conti GG, Bassi M, Carminucci D, Gatti L, Bocci AM (1990) Preinoculation with tobacco necrosis virus enhances peroxidase activity and lignification in cucumber, as a resistance response to Sphaerotheca fuliginea. Journal of Phytopathology 128:191-202.

Cox CM, Garret KA, Bowden RL, Fritz AK, Dendy SP, Herr WF (2004) Cultivar mixtures for the simultaneous management of multiple diseases: Tan spot and leaf rust of wheat. Phytopathology 94:961-969.

Crane GL, Calpouzos L (1969) Synergism of Cercospora beticola and beet yellows virus in killing sugar beet leaves. Phytopathology 59:1338-1339.

Dalla Pria M, Bianchini A, Souza EA (1994) Avaliação da resistência de dez cultivares de feijoeiro ao vírus do mosaico-em-desenho. In: $5^{\circ}$ Seminário sobre Pragas, Doenças e Plantas Daninhas do Feijoeiro, Resumos... Piracicaba SP, Brazil. FEALQ. p. 22. 
Damsteegt VD, Bonde MR, Hewings AD (1993) Interactions between maize streak virus and downy mildew fungi in susceptible maize cultivars. Plant Disease 77:390-392.

Donchev N, Mallinsky I, Iliev I (1980) Effect of leaf rust (Puccinia recondita $\mathrm{f}$. sp. tritici) on the development of powdery mildew (Erysiphe graminis f. sp. tritici) on wheat. Cereal Rust Bulletin 7:11-15.

Erasmus DS, Von Wechmar MB (1983) Reduction of susceptibility of wheat to stem rust (Puccinia graminis f. sp. tritici) by brome mosaic virus. Plant Disease 67:1196-1198.

Faria JC, Hagedorn DJ (1986) A multiple inoculation technique for selection of bean seedlings with resistance to three pathogens. Fitopatologia Brasileira 11:535-542.

Finke ML, Coyne DP, Steadman JR (1986) The inheritance and association of resistance to rust, common blight, plant habit and foliar abnormalities in Phaseolus vulgaris L. Euphytica 35:969982.

Francl LJ, Madden LV, Rowe RC, Riedel RM (1987) Potato yield loss prediction and discrimination using preplant population densities of Verticillium dahliae and Pratylenchus penetrans. Phytopathology 77:579-584.

García-Cano E, Resende RO, Fernández-Muñoz R, Moriones E (2006) Synergistic interaction between Tomato chlorosis virus and Tomato spotted wilt virus results in breakdown of resistance in tomato. Phytopathology 96:1263-1269.

Geuting G (1984) Wechselwirkungen zwischen Septoria nodorum und Erysiphe graminis f. sp. tritici auf Weizen. Mitteilungen aus der Biologischen Bundesanstalt für Land- und Forstwirtschaft. BerlinDahlem 223:96.

Gil-Salas FM, Peters J, Boonham N, Cuadrado IM, Janssen D (2012) Co-infection with Cucumber vein yellowing virus and Cucurbit yellow stunting disorder virus leading to synergism in cucumber. Plant Pathology 61:468-478.

Goodman RM, Ross F (1974) Enhancement by potato virus Y of potato virus $\mathrm{X}$ synthesis in doubly infected tobacco depends of the timing of invasion by the viruses. Virology 58:263-271.

Gordon DT, Schmitthenner AF (1969) Association of soybean mosaic virus with tobacco ringspot virus in soybean bud blight. Phytopathology 59:1028.

Graham JH, Devine TE, Hanson CH (1976) Occurrence and interaction of three species of Colletotrichum on alfalfa in the midAtlantic United States. Phytopathology 66:538-541.

Hamilton RI, Nichols C (1977) The influence of bromegrass mosaic virus on the replication of tobacco mosaic virus in Hordeum vulgare. Phytopathology 67:484-489.

Harrison AL (1973) Control of peanut leaf rust alone or in combination with Cercospora leaf spot. Phytopathology 63:668-673.

Hau B, Meier F (1998) Modelling the dynamics of simultaneously occurring fungal leaf diseases and their interactions with host growth and defoliation of Phaseolus beans. In: $7^{\text {th }}$ International Congress of Plant Pathology, Proceedings... Edinburgh Scotland. British Society for Plant Pathology. p. 2.8.11.

Hedges F (1944) Association of Xanthomonas phaseoli and the common bean mosaic virus, Marmor phaseoli: I. Effect on pathogenicity of the seedborne infective agents. Phytopathology 34:662-693.
Hedges F (1946a) Association of Xanthomonas phaseoli and the common bean mosaic virus, Marmor phaseoli: II. Dissociation studies of $X$. phaseoli. Phytopathology 36:589-612.

Hedges F (1946b) Association of Xanthomonas phaseoli and the common bean mosaic virus, Marmor phaseoli: III. The effect of varying amounts of nitrogen on pathogenicity. Phytopathology 36:613-623.

Hobbs HA, Hartman GL, Wang Y, Hill CB, Bernard RL, Pedersen WL, Domier LL (2003) Occurrence of seed coat mottling in soybean plants inoculated with Bean pod mottle virus and Soybean mosaic virus. Plant Disease 87:1333-1336.

Hoffmann K, Geske SM, Moyer JW (1998) Pathogenesis of tomato spotted wilt virus in peanut plants dually infected with peanut mottle virus. Plant Disease 82:610-614.

Hoffman-Wolf U, Mayee CD, Sarkar S (1990) Synergismus zwischen Kartoffelvirus X und Kartoffelvirus Y: Mögliche Bedeutung der Virusstämme. Zeitschrift für Pflazenkrankheiten und Pflanzenschutz 97:168-186.

Holton CS, Jackson TL (1951) Varietal reaction to dwarf bunt and flag smut, and the occurrence of both in the same wheat plant. Phytopathology 41:1035-1037.

Hwang I, Lim SM (1992) Effects of individual and multiple infections with three bacterial pathogens on disease severity and yield of soybeans. Plant Disease 76:195-198.

Hyde PM (1978) A study of the effects on wheat of inoculation with Puccinia recondita and Leptosphaeria nodorum, with respect to possible interactions. Journal of Phytopathology 92:12-24.

Hyde PM (1981) The effects on wheat of inoculation with Puccinia striiformis and Septoria nodorum with respect to possible interactions. Journal of Phytopathology 100:111-120.

Jedlinski H, Brown CM (1965) Cross-protection and mutual exclusion by three strains of barley yellow dwarf virus in Avena sativa. Virology 26:613-621.

Jeger MJ (1986) The potential of analytic compared with simulation approaches to modelling in plant disease epidemiology. In: Leonard KJ, Fry WE (Eds.) Plant Disease Epidemiology. Vol. 1. Population Dynamics and Management. New York NY, USA. Macmillan Publishing Co.

Jenkins PD, Jones DG (1981) The effects of dual inoculation of wheat cultivars with Septoria tritici and Septoria nodorum. Journal of Phytopathology 101:210-221.

Jesus Junior WC, Vale FXR, Coelho RR, Hau B, Zambolim L, Costa LC, Bergamin Filho A (2001) Effects of angular leaf spot and rust on yield loss of Phaseolus vulgaris. Phytopathology 91:1045-1053.

Johnson KB, Radcliffe EB, Teng PS (1986) Effect of interacting populations of Alternaria solani, Verticillium dahliae, and the potato leafhopper (Empoasca fabae) on potato yield. Phytopathology 76:1046-1052.

Johnson KB, Teng PS, Radcliffe EB (1987) Analysis of potato foliage losses caused by interacting infestations of early blight, Verticillium wilt, and the potato leafhopper; and the relationships to yield. Journal of Plant Diseases and Protection 94:22-33.

Johnson KB (1990) Assessing multiple pest populations and their effects on crop yield. In: IRRI. Crop Loss Assessment in Rice. Los Banos The Philippines. IRRI. pp. 203-214.

Johnson KB (1992) Evaluation of a mechanistic model that describes 
potato crop losses caused by multiple pests. Phytopathology 82:363369.

Johnston CO (1934) The effect of mildew infection on the response of wheat leaf tissues normally resistant to leaf rust. Phytopathology 24:1045-1046.

Jones JB, Roane CW, WolfDD (1981) The effects of Septoria nodorum and Xanthomonas translucens f. sp. undulosa on photosynthesis and transpiration of wheat flag leaves. Phytopathology 71:1173-1177.

Jones JB, Roane CW (1982) Interaction of Xanthomonas campestris pv. undulosa or Psedomonas cepacia with Septoria nodorum in vitro and in vivo. Canadian Journal of Microbiology 28:205-210.

JörgE(1987)SynökologischeUntersuchungenüberWechselwirkungen im Agoökosystemen Winterweizen. Ph.D. Dissertation, Universität Giessen. Giessen Germany.

Kiel K, Hau B (2000) Wechselwirkungen zwischen Blattpathogenen (Uromyces appendiculatus und Colletotrichum lindemuthianum) an der Phaseolus-Bohne. Mitteilung aus der Biologische Bundesanstalt für Land- und Forstwirtschaft 376:403.

Kiessling U, Hoffmann GM (1985a) Interaktionswirkungen zwischen Erysiphe graminis f. sp. hordei und Puccinia hordei an Gerste unter Berücksichtigung epidemiologischer Aspekte. Journal of Plant Diseases and Protection 92:396-406.

Kiessling U, Hoffmann GM (1985b) Physiologische Effekte bei Interaktionen zwischen Echtem Mehltau (Erysiphe graminis f. sp. hordei) und Zwergrost (Puccinia hordei) an Gerste. Journal of Plant Diseases and Protection 92:407-416.

Koning G, TeKrony DM, Ghabrial SA (2003) Soybean seedcoat mottling: Association with Soybean mosaic virus and Phomopsis spp. seed infection. Plant Disease 87:413-417.

Koning G, TeKrony DM, Pfeiffer TW, Ghabrial SA (2001) Infection of soybean with Soybean mosaic virus increases susceptibility to Phomopsis spp. seed infection. Crop Science 41:1850-1856.

Kranz J, Jörg E (1989) The synecological approach in plant disease epidemiology. Review of Tropical Plant Pathology 6:27-38.

Kunwar IK, Singh T, Sinclair JB (1985) Histopathology of mixed infections by Colletotrichum truncatum and Phomopsis spp. or Cercospora sojina in soybean seeds. Phytopathology 75:489-492.

Kutzner B, Hellwald KH, Buchenauer H (1993) Systemic induction of resistance in Phaseolus vulgaris L. to tobacco necrosis virus (TNV) by Uromyces phaseoli (Pers.) Wint. Journal of Phytopathology 138:920.

Latch GCM, Potter LR (1977) Interaction between crown rust (Puccinia coronata) and two viruses of ryegrass. Annals of Applied Biology 87:139-145.

Le May C, Potage G, Andrivon D, Tivoli B, Outreman Y (2009) Plant disease complex: Antagonism and synergism between pathogens of the Ascochyta blight complex on pea. Journal of Phytopathology 157:715-721.

Lim LG, Gaunt RE (1986a) The effect of powdery mildew (Erysiphe graminis f. sp. hordei) and leaf rust (Puccinia hordei) on spring barley in New Zealand. I. Apical development and yield potential. Plant Pathology 35:54-60.

Lim LG, Gaunt RE (1986b) The effect of powdery mildew (Erysiphe graminis f. sp. hordei) and leaf rust (Puccinia hordei) on spring barley in New Zealand. II. Epidemic development, green leaf area and yield. Plant Pathology 35:44-53.
Lopes DB, Berger RD (2001) The effects of rust and anthracnose on the photosynthetic competence of diseased bean leaves. Phytopathology 91:212-220.

Madariaga RB, Scharen AL (1984) Interactions of Mycosphaerella graminicola and Puccinia striiformis on wheat. Phytopathology 74:820.

Madden LV, Pirone TP, Raccah B (1987) Temporal analysis of two viruses increasing in the same tobacco fields. Phytopathology 77:974980.

Madeira AC, Fryett KP, Rossall S, Clark JA (1993) Interaction between Ascochyta fabae and Botrytis fabae. Mycological Research 97:1217-122.

Maino AL, Schroth MN, Vitanza VB (1974) Synergy between Achromobacter sp. and Pseudomonas phaseolicola resulting in increased disease. Phytopathology 64:277-283.

Manners JG, Gandy DG (1954) A study of the effect of mildew infection on the reaction of wheat varieties to brown rust. Annals of Applied Biology 23:271-301.

Marchoux G, Delecolle B, Selassie KG (1993) Systemic infection of tobacco by pepper veinal mottle potyvirus (PVMV) depends on the presence of potato virus Y (PVY). Journal of Phytopathology 137:283-292.

Marte M, Buonauro R, Della Torre G (1993) Induction of systemic resistance to tobacco powdery mildew by tobacco mosaic virus, tobacco necrosis virus or ethephon. Journal of Phytopathology 138:137-144.

Mascia T, Cillo F, Fanelli V, Finetti-Sialer MM, De Stradis A, Palukaitis P, Gallitelli1 D (2010) Characterization of the interactions between Cucumber mosaic virus and Potato virus $Y$ in mixed infections in tomato. Molecular Plant-Microbe Interactions 23:1514-1524.

Méndez-Lozano J, Torres-Pacheco I, Fauque CM, Rivera-Bustamante RF (2003) Interactions between geminiviruses in a natural occurring mixture: Pepper huasteco virus and Pepper golden mosaic virus. Phytopathology 93:270-273.

Morris SC (1982) Synergism of Geotrichum candidum and Penicillium digitatum in infected citrus fruit. Phytopathology 72:1336-1339.

Murphy JF, Kyle MM (1995) Alleviation of restricted systemic spread of pepper mottle potyvirus in Capsicum annum cv. Avelar by coinfection with a cucumovirus. Phytopathology 85:561-566.

Ngugi HK, Julian AM, King SB, Peacocke BJ (2000) Epidemiology of sorghum anthracnose (Colletotrichum sublineolum) and leaf blight (Exserohilum turcicum) in Kenya. Plant Pathology 49:129-140.

Ngugi HK, King SB, Holt J, Julian AM (2001) Simultaneous temporal progress of sorghum anthracnose and leaf blight in crop mixtures with disparate patterns. Phytopathology 91:720-729.

Nolan S, Cooke BM, Monahan FJ (1999) Studies on the interaction between Septoria tritici and Stagonospora nodorum in wheat. European Journal of Plant Pathology 105:917-925.

Odum EP (1953) Fundamentals of Ecology. Philadelphia PA, USA. W. B. Saunders Co.

Omar SAM, Bailiss KW, Chapman GP, Mansfield JW (1986) Effects of virus infection of faba bean on subsequent infection by Uromyces viciae-faba. Plant Pathology 35:535-543.

Pacheco R, García-Marcos A, Barajas D, Martiáñez J, Tenllado

F (2012) PVX-potyvirus synergistic infections differentially alter 
Interactions between foliar diseases: Concepts and epidemiological approaches

microRNA accumulation in Nicotiana benthamiana. Virus Research 165:231-235.

Panzer JD, Nickeson RL (1959) Delayed synergism of bacterial blight and bean mosaic on Phaseolus vulgaris L. Plant Disease Reporter 43:133-136.

Paula Júnior TJ, Jesus Junior WC, Morandi MAB, Bettiol W, Vieira RF, Hau B (2010) Interactions between aerial and soil-borne pathogens: mechanisms and epidemiological considerations. Pest Technology 4:19-28.

Pearson MN, Cole JS (1991) Further observations on the effects of Cymbidium mosaic virus and Odontoglossum ringspot virus on the growth of Cymbidium orchids. Journal of Phytopathology 131:193198.

Pearson MN, Cole JS (1986) The effects of Cymbidium mosaic virus and Odontoglossum ringspot virus on the growth of Cymbidium orchids. Journal of Phytopathology 117:193-197.

Pinnschmidt HO, Teng PS (1994) Advances in modeling multiple insect-disease-weed effects on rice and implications for research. In: Teng PS, Heong KL, Moody K (Eds.) Rice Pest Science and Management. Los Banos The Philippines. IRRI. pp. 101-128.

Pinnschmidt HO (1991) Effects of multiple pests on crop growth and yield. Philippine Phytopathology 21:1-11.

Pinnschmidt HO (1997) Simulation of host-parasite dynamics, crop loss, and effects of fungicide applications. In: Francl LJ, Neher DA (Eds.) Exercises in Plant Disease Epidemiology. St. Paul MN, USA. APS Press. pp. 166-174.

Pio-Ribeiro G, Wyatt SD, Kuhn CW (1978) Cowpea stunt: A disease caused by a synergistic interaction of two viruses. Phytopathology 68:1260-1265.

Pohl D, Wege C (2007) Synergistic pathogenicity of a phloem-limited begomovirus and tobamoviruses, despite negative interference. Journal of General Virology 88:1034-1040.

Potter LR (1980) The effects of barley yellow dwarf virus and powdery mildew in oats and barley with single and dual infections. Annals of Applied Biology 94:11-17.

Potter LR (1982) Interaction between barley dwarf virus and rust in wheat, barley and oats, and the effects on grain yield and quality. Annals of Applied Biology 100:321-329.

Potter LR, Jones IT (1981) Interaction between barley yellow dwarf virus and powdery mildew in four barley genotypes. Plant Pathology 30:133-139.

Powell NT (1979) Internal synergisms among organisms inducing disease. In: Horsfall JG, Cowling EB (Eds.) Plant Disease. Vol. 4. New York NY, USA. Academic Press. pp. 113-133.

Purdy LH, Holton CS (1963) Flag smut of wheat, its distribution and existence with stripe rust in the Pacific Northwest. Plant Disease Reporter 47:516-518.

Quinones SS, Dunleavy JM, Fisher JW (1971) Performance of three soybean varieties inoculated with soybean mosaic virus and bean pod mottle virus. Crop Science 11:662-664.

Raju DG, Sill WH, Browder LE (1969) The combined effects of two viral diseases and leaf rust on wheat. Phytopathology 59:14881492.

Rodriguez-Alvarado G, Kurath G, Dodds JA (1994) Symptom modification by satellite tobacco mosaic virus in pepper types and cultivars infected with helper tobamoviruses. Phytopathology 84:617-621.

Ross JP (1968) Effect of single and double infections of soybean mosaic and bean pod mottle viruses on soybean yield and seed characters. Plant Disease Reporter 52:344-348.

Ross JP (1969) Effect of time and sequence of inoculation of soybeans with soybean mosaic and bean pod mottle viruses on yield and seed characters. Phytopathology 59:1404-1408.

Savary S, Zadoks JC (1992a) Analysis of crop loss in the multiple pathosystem groundnut-rust-late leaf spot. I: Six experiments. Crop Protection 11:99-109.

Savary S, Zadoks JC (1992b) Analysis of crop loss in the multiple pathosystem groundnut-rust-late leaf spot. II: Study of the interactions between diseases and crop intensification in factorial experiments. Crop Protection 11:110-120.

Savary S, Zadoks JC (1992c) Analysis of crop loss in the multiple pathosystem groundnut-rust-late leaf spot. III: Correspondence analyses. Crop Protection 11:229-239.

Savary S, Willocquet L, Elazegui FA, Castilla NP, Teng PS (2000) Rice pest constraints in tropical Asia: Quantification of yield losses due to rice pests in a range of production situations. Plant Disease 84:357-369.

Shearer BL, Wilcoxson RD, Skovmand B, Anderson WH (1978) Infection of barley by Septoria avenae f. sp. triticea enhanced by Puccinia hordei. Journal of Plant Diseases and Protection 85:461470.

Sherwood JL, Reddick BB, Conway KE (1988) Reactions of Bahamian hot chile to single and double infections with tobacco mosaic virus and potato virus Y. Plant Disese 72:14-16.

Sikora RA, Carter WW (1987) Nematode interaction with fungal and bacterial plant pathogens - fact or fantasy. In: Veech JA, Dickson DW (Eds.) Vistas on Nematology. Hyattsville MD, USA. Society of Nematologists Inc. pp. 307-312.

Simkin MB, Wheeler BEJ (1974) Effects of dual infections of Puccinia hordei and Erysiphe graminis on barley, cv. Zephyr. Annals of Applied Biology 78:237-250.

Sommerfeld ML, Gildow FE, Frank JA (1993) Effects of single or double infections with Helminthosporium avenae and barley yellow dwarf virus on yield components of oats. Plant Disease 77:741-744.

Spadafora VJ, Cole JrH(1987) Interactions between Septoria nodorum leaf blotch and leaf rust on soft red winter wheat. Phytopathology 77:1308-1310.

Stevens C, Gudauskas RT (1983) Effects of maize dwarf mosaic virus infection of corn on inoculum potential of Helminthosporium maydis race 0. Phytopathology 73:439-441.

Stevens C, Gudauskas RT (1982) Relation of maize dwarf mosaic virus infection to increased susceptibility of corn to Helminthosporium maydis race 0 . Phytopathology 72:1500-1502.

Straib W (1938) Über den Einfluß der Steinbrandinfektion auf das Gelbrostverhalten des Weizens. Phytopathologische Zeitschrift 11:571-587.

Suheri H, Price TV (2000) Infection of onion leaves by Alternaria porri and Stemphylium vesicarium and disease development in controlled environments. Plant Pathology 49:375-382.

Teng PS, Johnson KB (1988) Analysis of epidemiological components 
in yield loss assessment. In: Kranz J, Rotem J (Eds.) Experimental Techniques in Plant Disease Epidemiology. Berlin West Germany. Springer. pp. 179-189.

Thomas NR, Chatarth MS (1976) On the relationship between susceptibility of loose smut infected plants to black rust and Helminthosporium blight. Indian Phytopathology 28:572-573.

Uyemoto JK, Claflin LE, Wilson DL (1981) Maize chlorotic mottle and maize dwarf mosaic viruses: effect of single and double inoculations on symptomatology and yield. Plant Disease 65:39-41.

Valverde RA, Heick JA, Dodds JA (1991) Interactions between satellite tobacco mosaic virus, helper tobamoviruses and their hosts. Phytopathology 81:99-104.

Van Der Wal AF, Shearer JC, Zadoks JC (1970) Interaction between Puccinia recondita f. sp. triticina and Septoria nodorum on wheat, and its effects on yield. Netherlands Journal of Plant Pathology 76:261-263.

Van Der Wal AF, Cowan MC (1974) An ecophysiological approach to crop loss exemplified in the system wheat, leaf rust and glume blotch. II. Development, growth, and transpiration of uninfected plants and plants infected with Puccinia recondita f .sp. triticina and/or Septoria nodorum in a climate chamber experiment. Netherlands Journal of Plant Pathology 80:192-214.

Varughese J, Griffiths E (1983) Effect of barley yellow dwarf virus on susceptibility of barley cultivars to net blotch (Pyrenophora teres) and leaf blotch (Rhynchosporium secalis). Plant Pathology 32:435-440.

Waggoner PE, Berger RD (1987) Defoliation, disease, and growth. Phytopathology 77:93-398.

Waggoner PE (1986) Progress curves of foliar diseases: Their interpretation and use. In: Leonard KJ, Fry WE (Eds.) Plant Disease Epidemiology. Vol. 1. Population Dynamics and Management. New York NY, USA. Macmillan Publishing Co. pp. 3-37.

Wainwright A, Kenny MA, Yarham DJ (1986) Increased susceptibility to Septoria nodorum in winter wheat infected by Tilletia caries. Plant Pathology 35:582-584.

Walkey DGA, Payne CJ (1990) The reaction of two lettuce cultivars to mixed infection by beet western yellows virus, lettuce mosaic virus and cucumber mosaic virus. Plant Pathology 39:156-160.

Wallace HR (1983) Interactions between nematodes and other factors on plants. Journal of Nematology 15:221-227.

Waller JM, Bridge J (1984) Effects of pathogen interactions on tropical crop production. In: Wood RHS, Jellis GJ (Eds.) Plant Diseases: Infection, Damage and Loss. Oxford UK. Blackwell Scientific Publications. pp. 311-320.

Wang Y, Gaba V, Yang J, Palukaitis P, Gal-On A (2002) Characterization of synergy between Cucumber mosaic virus and potyviruses in cucurbit hosts. Virology 92:51-58.

Weber GE, Gülec S, Kranz J (1994) Interactions between Erysiphe graminis and Septoria nodorum on wheat. Plant
Pathology 45:158-163.

Weber GE (1996) Modelling interactions between epidemics of Erysiphe graminis and Septoria nodorum on wheat. Journal of Plant Diseases and Protection 103:364-376.

Williams DJ, Nyvall RF (1980) Leaf infection and yield losses caused by brown spot and bacterial blight diseases of soybean. Phytopathology 70:900-902.

Willingale J, Mantle PG (1987) Interactions between Claviceps purpurea and Tilletia caries in wheat. Transactions of the British Mycological Society 89:145-153.

Wilson EM (1958) Rust-TMV cross protection and necrotic ring reaction in bean. Phytopathology 48:228-231.

Wintermantel WM (2005) Co-infection of Beet mosaic virus with beet yellowing viruses leads to increased symptom expression on sugar beet. Plant Disease 89:325-331.

Wisler GC, Lewellen RT, Sears JL, Wasson JW, Liu HY, Wintermantel WM (2003) Interactions between Beet necrotic yellow vein virus and Beet soilborne mosaic virus in sugar beet. Plant Disease 87:1170-1175.

Xi D, Feng H, Lan L, Du J, Wang J, Zhang Z, Xue L, Xu W, Lin H (2007) Characterization of synergy between Cucumber mosaic virus and Tobacco necrosis virus in Nicotiana benthamiana. Journal of Phytopathology 155:570-573.

Xi D, Yang H, Jiang Y, M Xu, Shang J, Zhang Z, Cheng S, Sang L, Lin H (2010) Interference between Tobacco necrosis virus and Turnip crinkle virus in Nicotiana benthamiana. Journal of Phytopathology 158:263-269.

Yang H, Wang S, Xi D, Yuan S, Wang J, Xu M, Lin H (2010) Interaction between Cucumber mosaic virus and Turnip crinkle virus in Arabidopsis thaliana. Journal of Phytopathology 158:833836.

Yarwood CE (1977) Pseudoperonospora cubensis in rust-infected bean. Phytopathology 67:1021-1022.

Zadoks JC, Schein RD (1979) Epidemiology and Plant Disease Management. Oxford UK. Oxford University Press.

Zaiter HZ, Coyne DP, Steadman JR (1990) Coinoculation effects of the pathogens causing common bacterial blight, rust, and bean common mosaic in Phaseolus vulgaris. Journal of the American Society for Horticultural Science 115:319-323.

Zhang XY, Loyce C, Meynard JM, Savary S (2006) Characterization of multiple disease systems and cultivar susceptibilities for the analysis of yield losses in winter wheat. Crop Protection 25:10131023.

Zhou Y, Fitt BDL, Wleham SJ, Evans N, Gladders P (2000) Effects of stem canker (Leptoshaeria maculans) and light leaf spot (Pyrenopeziza brassicae) on yield of winter oilseed rape (Brassica napus) in southern England. Plant Pathology 49:487-497. 